\title{
SOCIAL CAPITAL AND LOCAL DEVELOPMENT ACTIVITIES:
} A RURAL DEVELOPMENT PERSPECTIVE

Pasa, Rajan Binayek ${ }^{7}$

\begin{abstract}
This paper examined the status of social capital and local development activities in Thapagaun village of Kirtipur Municipality. The focus has been given to explore role of social capital on local development from the perspective of rural development. More so, under the mix method study design, ethnographic methodology has been applied. In so doing, I selected 28 total households of Thapa community as respondents and also selected four participants from migrated households as participants purposively. The necessary primary data was collected and generated through household survey questionnaire, in depth interview and participant observation whereas secondary information generated from municipality profile, published journal articles and books. More specifically the study revealed with three types of social relationships (i.e. bonding, bridging and linking) that have been improving socio-economic and cultural life of the villagers in the study area. This study found that socio economic, cultural and educational status of the respondents have been playing key role for forming social capital and promoting local development activities though condition of road networking and transportation facilities are still found to be unsatisfactory. However, women are thoughtfully playing socio-economic and cultural role in the community as an outcome of social capitals. Finally, the study realized that reciprocal relationship among villagers and linking relationship with politicians/ bureaucrats have been affected local development activities in this community
\end{abstract}

Keywords: Community, Local Development, Rural Development and Social Capital Background

The concept of social capital originally emerged from sociology to describe the status of available resources to the individuals through their collective behaviors and productive membership in community networks. In contrast to human capital, embodied

\footnotetext{
${ }^{7}$ Mr. Pasa is PhD scholar, Faculty of Humanities and Social Sciences, Tribhuvan University Assistant Professor, Central Department of Rural Development, Tribhuvan University. Email: rbpshrestha_1942@yahoo.com 
in individuals' investment in education and job training, local development activities, social capital described to exist in the structure and quality of social relationships between individuals or community members (Kawachi, 1999). Social capital generally described as concepts like sociability, social networks, social connectedness, trust, reciprocity, civic engagement, sense of identity, and norms. The individual's amount of social capital depends on how large network of relations he/she effectively can mobilize, and on the amount of capitals (i.e. economic, cultural and symbolic), each member of the network possesses. Therefore, social capital is an attribute of an individual in a social context. One can acquire social capital through purposeful actions and can transform social capital into conventional economic gains reasoning that social capital depends on the person's connections (Bourdieu, 1998).

Social capital also defined as those features of social organization, such as trust, norms and networks that can improve the efficiency of society by facilitating coordinated actions. Dense networks of interaction probably broaden the participants' sense of self, developing the 'I' into the 'We', or enhancing the participants' 'taste' for collective benefits" (Putnam,1995). Putnam also reviews evidence that schools, neighborhoods, economy, democracy, health, and happiness depend on stocks of three types of social capitals (i.e. bonding, bridging and linking social capital). Bonding capital means social cohesion within a group structure. While bridging capital refers to the type of social capital that links, or cuts across, different communities/groups. Similarly, linking capital means power relations within a social capital. There is also a horizontal/vertical construct of social capital. The vertically based social capital inheres in the relationships between different levels of society (community, local, government), while the horizontally based exists in the relationships between similar individuals or groups in the same social context between communities (Harpham et al., 2002).

Similarly, rural development is overall development of rural areas with view to improve the quality of life of rural people. It is comprehensive and multidimensional concept and encompasses the development of agriculture and allied activities, village industries and crafts socio-economic infrastructures in rural areas (Singh, 1999). Conceptually, rural development is a development strategy that can be designed to improve the socio-economic life of rural poor; as such it involves extending the benefits of development to poorest in 
rural areas e.g. small farmers, tenants, landless and other disadvantage groups (World Bank [WB], 1975 as cited in Chaudhary \& Pasa, 2015). Theoretically, rural development seeks to alleviate poverty, mass utilization of resources, and commercialization of agriculture, creating opportunities, infrastructural development and modernization of society.

Therefore, in case of rural development through commercialization of agriculture based activities, Nepalese farmers can also become rational actors who would react to changes and apply transformative farming system, if they have given real opportunities related to agriculture inputs like; seeds of high value crops, fertilizer, irrigation facilities, price policy as well as intensification/diversification of productions (Chaudhary \& Pasa, 2015).The process of rural development at least should be more concerned on building and promoting social capital that can transform unproductive social networking into productive one, poor status of social capital into quality one instead of physical and social infrastructures and subsistence farming into locally initiated commercial farming. Here is why, the paper tries to analyze and appraise the productive role of social capital in local development activities so that social capital can be applied as one of the fruitful strategies for rural development throughout the country.

Literature says that community is a socially organized people residing in a specific geographic area which live according to shared values, ideas, norms and principles that interact through relationship that have evolved over time (Shrestha, 2009). And better status of social capital can positively affect the community development activities that destinations attract to migrants. People can learn many more ideas in those destination areas where community member are found to be more cooperative, helping, collective in nature that help to overall development of community. World Bank and organization on economic cooperation and development, praises the positive impact of "high levels" of social capital on well-being, economic growth, health, educational performance, government efficiency, security and so on (Ponthieux, 2004). Social capital then has played crucial role in the functioning of community life across a variety of domains spanning from the prevention of juvenile crime, the promotion of successful youth development, the development of norms of labor market attachment, the enhancement of schooling and education, the smooth functioning of democracy and the advancement of local development activities and economic development (Kawachi, 1999). 
However, Nepal is a least developing country where majorities of the people $(21,970$, 684 out of 26,494,504) are living in rural areas. In rural areas there are also 125 ethnics and 123 lingual groups who are living in very homogenous and diversified community groups (Central Bureau of Statistics (CBS, 2011)). Subsistence agriculture is a primary occupation of the vast rural people it is the main source of livelihood. In terms of numbers, out of the 5.4 million households, 3.8 million households or about 71 percent are farming households (National Agriculture Census (NAC), 2011/12). But from the perspectives of rural development still most of the rural people are trapping in the vicious circle of poverty and there is also poor availability of resources and service delivery opportunities. Status of local development activities is also not satisfactory though government and non-government program have been implemented annually. Still most of the rural development programs are focusing on physical and infrastructure development rather than concerning on building social capital and networking among villagers just for their meaningful participations in local development activities.

\section{Research Questions}

- What were/are the factors for promoting social capital in this particular community?

- What is the status of social capital (i.e. bonding, bridging and linking) in this particular community?

- In what situations, social capital has been affecting local development activities in this community?

\section{Methodological Mapping}

Under the mixed method the ethnographic case study design was used to explore the lived experiences of participants, critical reflection on the researching issues and generating narrative texts within socio-cultural contexts (Perakyla \& Rusuvuori, 2008). In-depth ethnographic interview, Observations and survey method is the major data collection tools used in this study. Both statistical and thematic approach was used in the study for the data analysis procedure.

Descriptive, exploratory and explanatory methods were used to analyze subjective and objective nature of field information. For maintaining quality standard, informed consent 
of participants, trustworthiness, reliability, validity/credibility even in information generation process and whole research process is assured.

\section{Locality at a Glance}

Thapagaun lies in ward number 6 of Kirtipur Municipality of Kathmandu District. The place is semi-urban in nature following both traditional and modern livelihood system. It is $10 \mathrm{~km}$ south far from the capital city. It is situated nearer the lap of Chandragiri range and Dakshinkali Bhanjayang in south, Fulchocki range in the east, Chandragiri Badbhanjang in the west and Himalayan range in the north. It has both historical and religious importance. The major historical and religious sites such as Matatirtha, Machhe Narayan, Baga Bhairab, Aadi Nath, Jal Binayek, Jalapa Devi Temples and Taudha Karkat Nagpokhari) are nearer from the study area. Thapagaun has more than nine decades of historical evidences. With regard to their lineage, first of all Thapa community migrated from Jumla valley to Pokhara first then they again migrated from Pokhara to Kathmandu before ninth decade. In Kathmandu, Thapa community members firstly settled in Sunakothi, Chobhar and Charghare. Thapagaun is now one of the parts of Charghare because still there is a close relationship among Basnet community (32 Households) of Charghare and Thapa community (28 Households) of Thapagaun. Before ninth decade both Thapa and Basnet community lived in Charghare. Basnet community has been celebrating their Guthi Puja yearly in April 15 on the venue of Bhairab Mandir nearby Charghare and Thapagaun.

In fact, community members of Thapagaun have a close tie, community sentiment and regulation in relationship with same community members and others. Similarly, they are being following their traditional norms, values and traditions. There is minimum intervention of modernization of culture, religion, specific occupation, nuclear family system and fundamentalism of political activities. They are being prefer to work in their field to produce seasonable vegetables, majority of the households are rearing animal husbandry especially cow for milk and goat for meat from the business purpose. Majorities of them prefer to have pure vegetarian food and milk. Modernization of culture, dress, norms and values still could not affect them though nuclear family system, secularism and acculturation have been practicing in increasing trends in overall country. 


\section{Discussions of Findings: Factors for Promoting Social Capital}

Social capital is a complex phenomenon. Reasoning that here might be role of various factors that can form and reform social relationship, social networking and ultimately social capital. But in this study actual household information, occupational and income status of the households, educational status of the family members and service delivery institutions in local level are presented however some information in other variables were also considered.

Table 1. House Hold Information

\begin{tabular}{|l|c|c|c|c|c|}
\hline Households & Male & Percent & Female & Percent & Total \\
28 Local & 67 & 33.16 & 69 & 34.15 & 136
\end{tabular} \mid
\begin{tabular}{|l|c|c|c|c|c|} 
16 Rented & 35 & 17.32 & 31 & 15.34 & 66 \\
44 Total & $\mathbf{1 0 2}$ & $\mathbf{5 0 . 4 8}$ & $\mathbf{1 0 0}$ & $\mathbf{4 9 . 4 9}$ & $\mathbf{2 0 2}$ \\
\hline Households & & & & & \\
\hline
\end{tabular}

(Field Survey, 2016).

The table (1) highlights the information on composition of total population in particular community. From the table it is clearer that there are total 44 households (28 local and 16 rented Households) with total population 202. Male population 50.48 percent found slightly more than female population that is 49.49 percent as well. There is 4.6 family size per households which is minimum than national average 5.8. This fact and figure indicate that there is a good status of population management in given community which is one of the determinant factors for good health, happiness and socio-economic well-being. Further it was due to women empowerment there is an active role of women in decision making even in productive and reproductive sectors.

Table 2. Occupational Status of Local Households

\begin{tabular}{|c|c|c|c|c|}
\hline Occupation & Households & Percent & $\begin{array}{l}\text { M o n t h l y } \\
\text { Income NRs }\end{array}$ & $\begin{array}{l}\text { M/Expenditure } \\
\text { NRs }\end{array}$ \\
\hline Govt. service & 4 & 14.28 & $<20000$ & $>10000$ \\
\hline Army or pension & 12 & 42.85 & $20000-25000$ & $>20000$ \\
\hline Private job & 6 & 21.42 & $15000-20000$ & $<15000$ \\
\hline Business & 2 & 7.14 & $>50000$ & $<25000$ \\
\hline
\end{tabular}




\begin{tabular}{|l|l|l|c|c|} 
Agriculture & 1 & 3.57 & $20000-30000$ & $>20000$ \\
Remittance & 2 & 7.14 & $>30000$ & $<15000$ \\
Land Broker & 1 & 3.57 & $<20000$ & $<15000$ \\
\hline
\end{tabular}

(Field Survey, 2016).

The table (2) depicts the information on occupational and monthly income status of the local households. From the given table it is found that most $(42.85 \%)$ of the households are belong to army/pension occupation with approximately 20,000-25,000 NRs monthly income and less than 20,000 NRs monthly expenditure and least equal 3.57 percent households are following agriculture and land broking as a primary occupation with 20,000-30,000 NRs monthly income and 15,000- 20,000 NRs monthly expenditure. Similarly, private job, government job business and remittance are followed by 21.42 , 14.28 and equal 7.14 percent households. Very interestingly household with agriculture occupation earned highest or up to 30,000 NRs monthly income but household with business occupation expensed highest or up to 25,000 NRs monthly. This fact indicates good income status of each household. Thus, productive occupation and good status of monthly income helps to build economic relationship among each household. During my observation I also found majorities of the households' members are investing in productive sectors (commercial farming, animal husbandry and child education). Likewise, there is a good trust among each family member who have been running their own managed institutional school for quality education and cooperatives for collecting and mobilizing their earnings.

\section{Table 3. Occupational Status of Rented Households}

\begin{tabular}{l|r|r|c|c|}
\hline Occupation & HHs & Percent & Monthly Income NRs & M/Expenditure NRs \\
Construction labor & 4 & 25 & $>20000$ & $>10000$ \\
Agriculture+ Wage & 4 & 25 & $>25000$ & $<15000$ \\
Tunnel Farming & 3 & 18.75 & $>50000$ & $>25000$ \\
Govt. service/ & 2 & 12.5 & $<20000$ & $>15000$ \\
Army & & & & $<20000$ \\
Private job & 1 & 6.25 & 25000 & $>10000$ \\
Remittance & 1 & 6.25 & 15000 & $>15000$ \\
Student & 1 & 6.25 & - & \\
\hline
\end{tabular}


(Field Survey, 2016).

The table (3) illustrates the information on occupational and monthly income status of the migrated or rented households. From the given table it is found that most (equal $255 \%$ ) of the households are belong to construction labor and agriculture-based wage labor with 20,000-25,000 NRs monthly income and 10,000-15,000 NRs expenditure and least (equal 6.25\%) of the households are belong to private job, remittance and student occupational status 15,000-25,000 NRs monthly income and 10,000-20,000 NRs expenditure. Similarly, tunnel farming and government jobs are followed by 18.75 and 12.5 percent households with 20,000-50,000 NRs monthly income and 15,000-25,000 NRs expenditure. This fact also indicates good income status of each household. Thus, productive occupation and good status of monthly income of the migrated household was definitely because of laborious working life and productive wages and accessibility of vegetable marketing facilities. During my observation I found majorities of the students are involving in institutional schools and private college.

\section{Table 4. Educational Status of Local Households}

\begin{tabular}{|c|c|c|c|c|c|c|c|c|c|}
\hline Parent's & Male & $\%$ & Female & $\%$ & Children & Male & $\%$ & Female & $\%$ \\
\hline Primary & 14 & 50 & 19 & 68 & $<\mathrm{SLC}$ & 17 & 43.58 & 21 & 51.21 \\
\hline IA & 2 & 7.14 & 2 & 7.14 & $10+2$ & 9 & 23.07 & 8 & 19.51 \\
\hline BA & 4 & 14.28 & 1 & 3.57 & BA & 4 & 10.25 & 4 & 9.75 \\
\hline MA & 3 & 10.71 & 1 & 3.57 & MA & 2 & 5.12 & 2 & 4.87 \\
\hline $\mathrm{PhD}$ & 1 & 3.57 & - & - & No school & 7 & 17.94 & 6 & 14.63 \\
\hline Illiterate & 4 & 14.28 & 5 & 17.85 & & & & & \\
\hline Total & 28 & 100 & 28 & & & 39 & 100 & 41 & 100 \\
\hline
\end{tabular}

(Field Survey, 2016).

The table (4) shows the information on educational status of the local household members. From the data fact it is found that in case of parents most (50\% male and $68 \%$ female) passed primary level education and least (3.57\% male and equal 3.57\% female) passed $\mathrm{PhD}$ degree and BA/MA education level. Similarly, 14.28 percent male and 17.85 percent female found illiterate. In case of child education most (17\% male and $21 \%$ female) student are reading in primary level and least (5.12\% male and $4.87 \%$ female) students are reading in master degree level. Similarly, 17.94 percent male and 14.63 percent female 
have no educational status due to early age and health problem. The data indicates that both parents and children have good educational status that the reasons may parents have informed understanding on importance of higher education and thus investing in child education just for higher rate of returns.

\section{Table 5. Educational Status of Rented Households}

\begin{tabular}{|c|c|c|c|c|c|c|c|c|c|}
\hline Parent's & Male & $\%$ & Female & $\%$ & Children & Male & $\%$ & Female & $\%$ \\
\hline Illiterate & 4 & 26.3 & 6 & 40 & $\begin{array}{l}\text { Higher } \\
\text { study }\end{array}$ & 4 & 20 & 2 & 12.5 \\
\hline Primary & 2 & 13.4 & 4 & 26.3 & Secondary & 2 & 10 & 2 & 12.5 \\
\hline $\begin{array}{l}\text { L / } \\
\text { secondary }\end{array}$ & 2 & 13.4 & 2 & 13.4 & $\begin{array}{c}\mathrm{L} / \\
\text { secondary }\end{array}$ & 3 & 15 & 3 & 18.8 \\
\hline Secondary & 4 & 26.3 & 1 & 6.7 & Primary & 9 & 45 & 6 & 37.5 \\
\hline $\begin{array}{l}\mathrm{H} \text { i g h e r } \\
\text { study }\end{array}$ & 3 & 20 & 2 & 13.4 & No school & 2 & 10 & 3 & 18.8 \\
\hline Total & 15 & 100 & 15 & 100 & & 20 & 100 & 16 & 100 \\
\hline
\end{tabular}

(Field Survey, 2016).

The table (5) shows the information on educational status of the rented household members. From the data fact it is found that in case of parents most ( $26.3 \%$ male and $40 \%$ female) are illiterate and least equal 13.4 percent male passed primary and lower secondary level and same percent female passed lower secondary and higher-level studies. In case of child education most (20\% male and $12.5 \%$ female) are involving in higher studies and least equal 10 percent male student are either reading in secondary level education or not involving in formal education life and equal 12.5 percent female students are involving in higher study and secondary level education. The data also indicates that majorities of the children are getting formal educational opportunities however most of the parents are illiterate. During my informal interaction with migrated children what I notified that most of the migrated parents are sending their children in community school but some of children are also reading in institutional schools. But very interestingly secondary school passed students are involving private college for higher education. Their parents are investing in child education maybe they are planning to change the occupational status of the children in future or children themselves are encouraging their parents to invest for 
prosperous future of the family members.

\section{Table 6. Local Service Delivery Institutions}

\begin{tabular}{|c|c|c|c|}
\hline $\begin{array}{l}\text { Institutions } \\
\text { Primary school }\end{array}$ & $\begin{array}{c}\text { Government Led } \\
\text { Yes (1) }\end{array}$ & Community Led & Women Led \\
\hline Institutional school & & Yes (1) & \\
\hline Cooperatives & & Yes (2) & Yes (2) \\
\hline Guthi & & Yes (2) & \\
\hline Temple & & Yes (2) & \\
\hline Local shops & & Yes (2) & \\
\hline Total Institutions 12 & 1 & 9 & 2 \\
\hline
\end{tabular}

\section{(Field Survey, 2016).}

The table (6) depicts the information on accessibility of local service delivery institutions in this community. From the given fact it is found that there is very good networking of institutional development practice. Each community member is being involving in 12 different locally managed institutions. From which 2 institutions are totally led by women group remaining are leading by both men and women group. Talking about govt. led primary school in particular community there are not more than 7 students in 1-3 class and all of them are from another community. This fact and figure indicate that members of this community are seems profit motive and very smart in economic mobilization i.e. collecting, allocating and investing in commercial sectors. But because of religious belief and cultural reproduction practice they are still following their traditional norms, values and cultural systems and becoming far from modern cultural practices however in case of child education they are following modern education. No doubt, it was/is an institutional networking the members of the community are bonded with good status of social capital that has been resulting economic wellbeing of the community members and others.

\section{Status and Impact of Social Capital}

For appraising status and impact of social capital in this particular community as a qualitative researcher I understood that collecting and analyzing rigorous subjective data information is inevitable. Thus, I conducted ethnographic interview with participants just for valuing their subjective expressions on researching phenomenon. My first participant 
who has been playing leading role in this community since he got retired from his government job. He further responded to the lived experience on status and impact of social capital with the following remarks:

Here in our community we were/are practicing mutual relationship with own community members and others. We are also establishing good socio-economic relationship with own relatives, neighboring community members, rented or migrated family members and we are still close with top level politicians and bureaucrats. I can say that status of social relationship and social capital in this community is so far unique and productive as compare to others. It is one of the reasons I affirm that we are living with socioeconomic well-being and better livelihood. We are unique in terms of collectiveness and strong social relationship either in our Thapa community who are being living either inside or outside the valley or in another caste group. I am an army retired person thus, I have informed disciplined about family and community development. That is why I am playing social role and leadership role in the society just for maintaining and promoting the status of social relationship and also trying to diffuse our strong trust and relationship for other community too. We are also involving in sustainable livelihood and local development activities with meaningful participations as we realized we are also responsible stakeholders for community and local development. Even though we aged people are also involving in daily livelihood activities such as worship, prey and household works that can directly or indirectly affect our children's attitude and behavior. So even in my old age I have been supplying milk and vegetable in our local market and my house wife also played supportive role by engaging in commercial vegetable farming (B. Thapa, 12th September, 2016 (INT)).

The participant here reflected that community members themselves can make their social structure and function what structuralism and functionalism claimed that society is a function of social structure and different function but we can also find agency approach within a community member who are being practicing community development through collectiveness socio-cultural reproduction and production practices. From the vantage point of socialization theory parents are also socializing their children by right livelihood practices and giving worth value to work and worship. As a researcher I felt that it was due to their productive relationship with self and others, they became success to 
accelerate their sustainable livelihood and local development activities. In reference to the research findings on social capital it has also focused that social capital have now sought to recognize that for positive developmental outcomes there is a need both bonding (relationships within a group of people), and for bridging (external connections) and linking (relationship with those who have power) social capital (Winter, 2000).

From my first participant as I notified that in this community women are playing economic and social role in the society. They are forming women groups for saving and credits and also engaging in commercial farming system and also participating in local level for various local development activities. I wanted to triangulate his information with my second participant a middle-aged beautiful woman with typical cultural dress and smiling face with happy feeling. I selected her because she was also playing productive and transformative agency role in the community. During our interactions I found she was quite happy with good social relationship among relatives and villagers that have positively affected social and local development activities as well as social control in the society. More precisely for responding our interview she shared:

Socio-cultural control and good reciprocal relationship in our community is because of women as we are playing social and economic role. Along with our daily household works and agriculture-based works, we women group in this community are leading two cooperatives for saving and credit purpose. Right from the beginning when I got married I never felt that women are passive actor and must revolving for household's chores i.e. unproductive working life. Therefore, I have been involving in productive working life as compare to my husband. Here I must say that because of my economic role no need to dependent upon husband income for livelihood struggle. Now my husband is engaged in transportation service with own means and earning more than forty thousand per month. I am also engaging in commercial vegetable farming and I am also rearing 4 cows with various purposes especially compost fertilizer for farming and dairy products for commercial purpose and personal purpose. Most of women in our village are also engaging in local politics and participated in various awareness raising and skill development training in local level. However, it is very hard to work in farming, animal husbandry, supplying own products and social sector but it was/is possible due to our Parma system that has been practicing for farming, harvesting and supply our 
products in the market. We do daily supply our product in Balkhu, Khahare and Kirtipur market. From agro production I am also earning more or less same while compare with my husband. I have my personal and my son's share in cooperatives which are leading by us (L. Thapa, 15th October, 2016, (INT)).

The narrative data here implies that women are one of the actors of local development and have a capacity to socio-cultural control. Again, I analyzed that there is both bonding, bridging and linking social capital within community members and also there found vertical and horizontal social capital, cheap labor exchange i.e. Parma system and trust among women groups who are being leading cooperatives and earning equal amount from animal rearing and caring vegetable farming with compare to their husbands. Women group are also making their cultural norms more productive. They are well familiar with central level information too. It means that women role in production and socio-cultural control and protection is inevitability for promote status of social capital in any particular community. Here in my reflection the major factor of women empowerment and motivating them for playing economic and social role is due to their increasing awareness level and skill development acquired from frequent exposure visit and short-term training that was impossible if they community situated far from the Kathmandu Valley. Reflecting upon this situation the reference claimed that the direct benefit of social capital in social capital is information: for the focal actor, social capital facilitates access to broader sources of information and improves information's quality, relevance, and timeliness (Coleman, 1988). More so, during my participant observation, I found women of this community are actively participating in daily livelihood activities. Their household activities begin from 3 AM early in the morning and finished when sun set in on the top of Chandragiri range. They prefer to have a dinner after sun set and early to sleep. They start their daily activities from morning Bath and worship. Most of them are rearing domestic animals for commercial-farming in which women are found laborious and hard worker among household members; reasoning that women are actively engaging in financial, social, cultural and institutional development process.

For generating ideas from young generation who are involving in higher educational voyage, I decided to conduct common ethnographic interview with male and female student. My next participants were Kamal Thapa (name changed) and Manisha Thapa 
(name changed) who were student of higher education. They responded their experiences on status and impact of social relationship, cultural behavior and community sentiment with the following remarks:

Our parents are culturally rigid but perfect disciplined and laborious for maintaining good health, better economic status and best socio-cultural relationship with self and others. Very few parents in this community have habits of smoking, drinking alcohol and playing cards. They are very much smart for watching behaviors of own children and also updating with daily life activities either in village or in college. They often counsel us about our role and responsibility, to be a responsible citizen in our country and motivates for good educational achievements and productive future life. They are highly religious we could not play English and pub music in our mobile and are not allowed to do internet connection in our home it is because it is harmful for teenagers because of pornography. But in case of status of land property majorities of household members have not land registration certificate because more than 38 ropani lands in our community are under Birta land and more than 21 ropani land is under Guthi land. We think it was/is one of the determinant causes for maintaining strong unity among each member who are struggling collectively to make this land from Birta and Guthiinto Raiker i.e in personal registration (G. Thapa, 18th October, 2016, [INT]).

From the given text what I analyzed that there is a very less intervention of cultural modernization in given community. I found traditional culture is a means of social control too because young generation are following their parent's instructions and directions in their daily livelihood and life activities. Thus, I found their cultural reproduction as a symbol of cultural production which able to socialize their children under their own cultural and religious norms and values and rule and regulations. And their unity is found productive and collective because of common problem in land property it means that they have a common goal to make this land into Raiker. Reflecting upon this situation I agree with the ideas of Coleman who highlighted two broad intellectual streams in the explanation of social action. The first is the sociological approach, which sees the individual in a social and cultural environment, subject to 'norms, rules, and obligations. The second is the economic approach, which is about self-interested, independent individuals seeking to fulfill their goals (Coleman, 1988). 
Along with reflective ideas of young generation I also wanted to triangulate the information of local people who shared that they were/are playing cooperative and supporting social role with others or migrated/rented households. For that purpose, I selected one of the migrated families from Gorkha District who was my fourth participant. During our interactions with researching issues he thoughtfully shared his own experiences with the following remarks:

My family has been living in this community in the last 7 years. Because of poverty, poor social support and poor relationship with own relatives and other neighboring members, I decided to migrate in Kathmandu Valley or in urban centers where there is a employment opportunities and good networking of service delivery. Thus, I migrated here without any property but with 5 family members. Because of my laborious working life and multiple skills like; carpenter, mason and various technical works I got opportunities to convert my skills into cash. However, my house wife also engaging in agriculture based daily wage labor activities for this community and neighboring communities. Now we have a saving account in cooperative, our children are getting educational opportunities in which elder daughter and son are now in grade nine and younger son in grade two however they are getting educational service in community school. I must say that it is possible through community support and good relationship with each member of given community. I feel I am also the member of this community. Nobody behaves with our family as outsiders. Here I found well trust and reciprocal relationship among each members and Parma system for farming, harvesting and supplying products in to local market. I have 5 ropani lands in cheap rental and during farm activities we often used Parma system (R. Timilsina, 22th November, 2016, (INT)).

From the given text what I analyzed that there is a very good community support for outsiders also and outsiders also choose this destination on the basis of social relationships and locality. Migrated family members are learning new behavior and saving ideas in new destination area. From the vantage point of Todaro's migration theory, we found people migrated in new destination area due to possibility of high income and good service facility than in area of origin. That is the reason why, here the migrant also satisfies with his family income, child's schooling and form own socio-economic status in general and social support and reciprocal relationship in particular. It means that good 
status of social capital can attract new comers in particular community and engage in production and distribution activities that can help both software and hard ware part of local development activities in any particular community. However, in the beginning because of poor social structure and support system my participant suffers from various problems like poverty and unemployment, misery and domination in society and felt oppression and suppression even in own original society (Ritzer, 2000). Likewise, in each society majority of dominated people are being facing problem. But in the reference to the literature on socialization my participant ultimately got a chance for observing various types of activities that provided him to additional knowledge and skill regarding with daily work standard form neighborhoods and media (Adhikari, 2002).

\section{Current Status of Local Development Activities}

From my daily observation and field base, I appraised status and impact of social capital and local development activities in Thapagaun from rural development perspectives. I observed both Software part and hardware part of the development which are considered as a means and ends of development. Talking about software part of development, I found local people including male, female and children are nourishing their knowledge and developing their skills from formal, informal and non-formal education and trainings. They are promoting status of social capital one or another way that has directly affected feeling togetherness, building socio-economic relationship with self and others. Young generations are still following their traditional cultural norms and values. I saw most of children both male and female often worship in Bhairab Temple for better school performance and good luck. They are well disciplined, engaging in household's activities in their leisure time and sometimes engaging in economic activities such as daily supply of their dairy product and vegetables in Khahare, Balkhu and Kirtipur market too (Reflections from Daily Observation).

All women are found to be more empowered and again there could be seen gender development activities. Most of community level different activities i.e. local feast and festivals, cremation, worship, and financial activities are being led by women. Likewise, girls school going ratio is also high while compare with that of boys. There is no form of gender discrimination. Each young generation are following their daily rules and regulations such as daily bath, worship, study, leisure activities and HHs activities. And 
being a nearer from urban center the villagers are practicing Parma system or labor exchange during farming activities. I found cooperative, trust, feeling positive attitude and both physical and spiritual development of all members in particular community that has brought social cohesion, local cultural development and protection, social control and higher social respect for promoting social relationships. All members are very much conscious about their trust on exchanging new innovative knowledge and skill learned from various sources like; visit observation and reading and visual sources that can foster local development activities and socio-economic well-being. The literature on social capital also claims that better status of social capital can positively affect the community and local development activities where people can learn many more ideas in those destination areas where community member are found to be more cooperative, helping, collective in nature that help to overall development of community. In the process of diffusion of knowledge, skill, technology and ideas everything diffuses from center to periphery (Haggerstrand, 1952).

Better status of software part development of that community directly affected hard ware development activities in general. Talking about hard ware part development in particular community they have managed two drinking water project, sanitation project, and water cannel maintenance project in their collective initiation. They also built Bhairab and Kalimata Temples and collecting maintenance fund. After the massive earthquake most of the villagers built modern house building. And they are also collecting basked fund for reconstructing new Temple in same place. Similarly, they have run one institutional school, four cooperatives and two local Guthi as locally lead organizations. These institutions are only running by the strong collective representation and effort that we can call the capsule for forming and promoting status of social capital. They have also managed local road tracks that have linked this community with Khahare in south, Taudha and Bhutkhel in east, Chargharein north and Bhaktepati in west. Most portions of the fund was funded by their volunteer collection and also some from municipality.

\section{Findings and Conclusions}

Social capital plays crucial role in the functioning of rural community life especially for developing socio cultural norms, values, socioeconomic system and financial mechanism, providing educational opportunities to the children and overall mechanism 
for local development activities. However, the degree of social capital depends on socio cultural structures of any particular community. Even in this study area, it was/is because of bonding, bridging and linking social capitals, the status of community sentiment, trust, reciprocal relationship, community participation, institutional development, agro production through Parma system, economic well-being, and community support system found more satisfactory. Women empowerment and gender development activities are some of the fruitful outcomes of social capital in this community. Most of local activities (socio-cultural and financial) are being leading by women. Similarly, girls schooling ratio is also high while compare with that of boys. There is no form of gender discrimination. They often practice Parma system while cropping, harvesting and supplying products. Young generations are being following their cultural reproduction. All of them are well disciplined they prefer to concentrate in their education in HHs activities in leisure time. Most of the members are vegetarian. That crop trust and just feeling, positive attitude and both physical and spiritual development of all members that has brought social cohesion, local cultural development and protection, social control, respect to religious values and good livelihood activities. Thus, traditional culture seems here to be means of social control and cultural production. Community members are well kind, cooperative and helpful. Finally, the study comes up with the conclusion that quality status of social capital has been positively affecting local development activities in this village. The availability of 24 hours fresh drinking water supply, health and sanitation, road networking, institutional development, reciprocal relationship and cooperative behavior among local people and migrants indicate improved and transformed life and livelihoods of the villagers. The application of traditional cosmologies developed through Hinduism have been motivating villagers to perform ethical and responsible behaviors while living with thoughtful community member of this rural community located around Kirtipur Municipality.

\section{References}

Adhikari, R. R. (2002). An Introduction to Sociology and Anthropology, (6th ed.). Kathmandu: Biddharthi Pustak Bhandar.

Bourdieu, P. (1986). Forms of Capital in Handbook of Theory and Research for the Sociology Central Bureau of Statistics (CBS, 2012). Nepal Census report 2011. Author. 
Chaudhary, P. K. \& Pasa, R. B. (2015). Agriculture education for rural development in Nepal. Journal of Training and Development, 1 (1), 38-45. Author.

Coleman, J. (1988). Social capital in the creation of human capital. American Journal of Sociology 94, 95-120. Author.

Creswell, J. W. (2007). Qualitative inquiry and research design. California: Sage Publications.

Haggerstrand, T. (1952). The Propagation of Innovation Waves. Land Studies in Geography. Human geography 8 (4). Lund, Sweden.

Harpham, T. G. \& Thomas, E. (2002). Measuring Social Capital within Health Surveys: Key Issues. Health Policy and Planning 17(1), pp. 106-111. Author.

Kawachi, I. (1999). Social capital and community effects on population and individual health. Annals of the New York Academy of Sciences, 896, 120-130. Author.

Klemke, E. D., Kline, A. D. \& Hollinger, R. (1986). Philosophy: The basic issues, (2nd ed.). New York: St. Martin's Press.

National Agriculture Census (NAC). (2011/12). National Agriculture Census.

O’reilly, K. (2005). Ethnographic methods. London: Routledge.

Organization of Economic Culture and Development (2001). The Well-being of Nations:

The Role of Human and Social Capital. Paris: Author.

Perakyla, A. \& Ruusuvuori, J. (2008). Analyzing Talk and Text. In N. K. Denzin (Ed.), Handbook of arts in qualitative research (pp.117-125). Thousand oaks' London: Sage Publication.

Ponthieux, S. (2004). The Concept of Social Capital: A Critical Review. 10th ACN Conference. Paris: 21-23 January. Author.

Putnam, R. (1995). “Bowling Alone: America's Declining Social Capital”. Journal of Democracy, 6, 65-78. Author.

Ritzer, G. (2000). Sociological theories, (5th ed.). New York: McGraw Hill Companies 
House.

Shrestha, M. (2009). Community Development. Kathmandu: New Hira Book Publication.

Singh, K. (1999). Rural Development, Principle, Policies and Management (2nd ed.). New Delhi: Sage Publication.

Todaro, M. P. (1976). Internal migration in developing countries: a review of theory, evidence, methodology and research priorities: ILO World Migration Report, 2010.

Winter, I. (2000). Towards a Theorized Understanding of Social Capital, Working paper 21. Australian Institute of Family Studies. 